\title{
Bir Üniversite Hastanesinin Yoğun Bakım Ünitesi Hemşirelerinde Yaşam Kalitesi, iş Kazaları ve Vardiyalı Çalışmanın Etkileri
} Life Quality, Work Accidents and Effects of Shift Work in Intensive

Care Unit Nurses of a University Hospital

\author{
Didem Ata Yüzügüllü, Necdet Aytaç, Muhsin Akbaba \\ ' Çukurova Üniversitesi Tıp Fakültesi Halk Sağlığı Anabilim Dalı, Adana \\ Yazışma Adresi / Correspondence: \\ Didem Ata Yüzügüllï \\ Çukurova Üniversitesi Halk Sağlğı Anabilim Dalı Sarıçam/ADANA \\ T: +90 $5059414547 \quad$ E-mail: didemata8@gmail.com
}

Geliş Tarihi / Received : 19.01.2018 Kabul Tarihi / Accepted : 09.03.2018

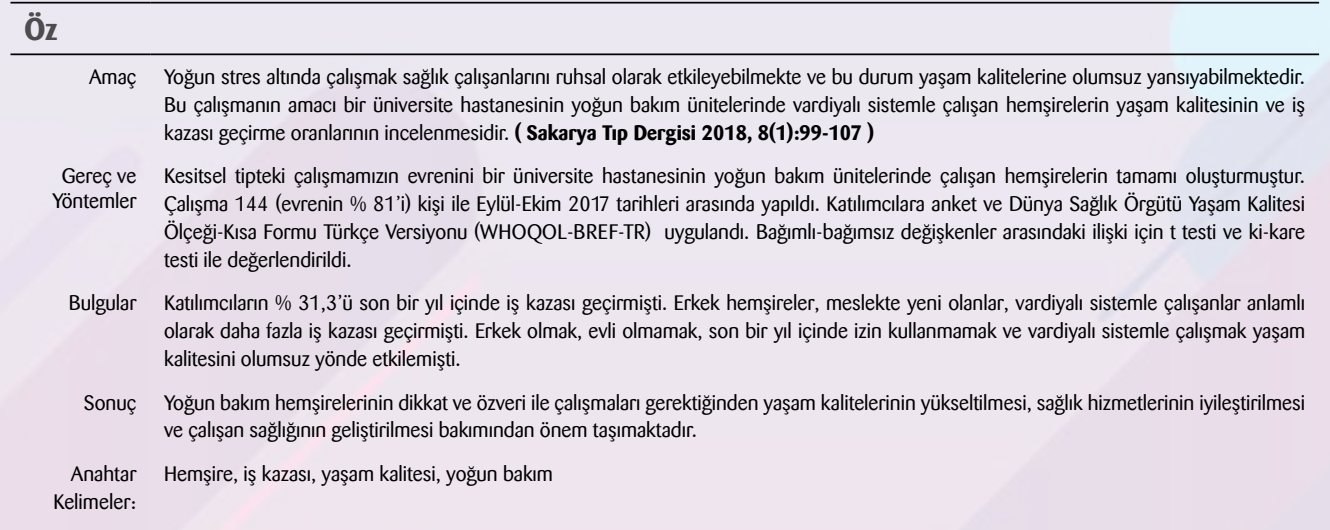

\section{Abstract}

Objective Working under intense stress can affect health workers psychologically and this can be reflected negatively on quality of life. The purpose of this study is to examine the quality of life and the rate of occupational accidents of nurses working in the intensive care units of a university hospital. ( Sakarya Med J 2018, 8(1):99-107).

Materials and All of the nurses working in intensive care units of a university hospital constituted the universe of our cross-sectional study. Our study was Methods conducted between September-October 2017 with 144 people ( $81 \%$ of the universe). Participatory questionnaires and the Turkish version of the World Health Organization Quality of Life Instrument (WHOQOL-BREF-TR) were administered. The t-test and chi-square test were used for the relationship between dependent and independent variables.

Results $\quad 31.3 \%$ of the participants had a work accident in the past year. Male nurses, those new to the profession, working with the shift system had spent significantly more work accident. Being a man, not being married, not using leave in the last year, and working with a shift system has affected the quality of life negatively.

Conclusion Since intensive care nurses need to work with care and self-sacrifice, it is important to improve quality of life, improve health services and improve working health.

Keywords Nurse, work accident, quality of life, intensive care 

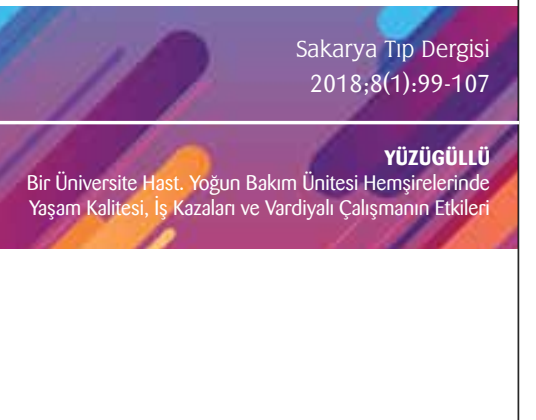

\section{Giriş}

Sağlık alanında görev yapan doktor, hemşire ve diğer yardımcı sağık personeli, çalışma koşulları gereğince yoğun stres altındadır. Nöbetler nedeniyle uyku düzeninin bozulması, ekonomik sorunlar, yoğun iş yükü, ağır ve ölümcül hastalara bakım verme, iş yerinde ilişki ve görev paylaşımı sorunlarının yaşanması sağlık çalışanlarında işle ilgili stres ve gerginliğe yol açmaktadır. ${ }^{1}$

Yoğun stres altında çalışmak sağlık çalışanlarını ruhsal olarak etkileyebilmekte ve bu durum yaşam kalitelerine olumsuz yansıyabilmektedir. Hemşireler ise hastalarla en uzun süre birlikte olan sağık çalışanları olup, hasta bireyin ve ailesinin her türlü sorunlarında ilk başvurduğu, anahtar roldeki sağlık personelidir. ${ }^{2}$

Vardiyalı çalışma, hemşireler için yaygın bir çalışma sistemidir. Çünkü hastanelerde tedavi gören hastalar yirmi dört saat bakıma ihtiyaç duymaktadır. ${ }^{3}$ Bu konuda yapılan birçok çalışmada gösterildiği gibi vardiyalı çalışma sistemi, sirkadyen ritmin bozulması, performans bozukluğu, uykusuzluk, sağlığın bozulması, fiziksel ve psikolojik sıkıntılar gibi problemleri de beraberinde getirir. ${ }^{4-6}$

Vardiyalı çalışma sistemi kişinin uyku kalitesinin de bozulmasına yol açar. Gün içinde yeterli uykuyu alamamanın sonucu olarak bedensel ve ruhsal sağlıkta etkilenmeler başlar. Bazı araştırmacılar uzun yıllar vardiyalı çalışmanın ve günde sekiz saatten az uyumanın özellikle duygusal alanlarda olumsuz etkilere neden olabileceğini vurgulamıştı. ${ }^{7,8}$

Özellikle yoğun bakımda çalışan hemşirelerin çoğu vardiyalı sistemle çalışmakta olup, bu çalışma sisteminin getirdiği sorunlarla baş etmek zorunda kalırlar. Vardiyalı çalışma sistemi, hemşireleri stres altına alarak, sağlık, esenlik ve yaşam biçimlerinin bozulmasına neden olabilir. ${ }^{9}$

İş kazası kavramının pek çok tanımı olmakla beraber, Uluslararası Çalışma Örgütü’nün yaptığı tanıma göre iş kazası; belirli bir zarara ya da yaralanmaya neden olan, beklenmeyen ve önceden planlanmamış bir olaydır. ${ }^{10}$ Ülkemizde hastanelerin "Çok Tehlikeli iş̧ler" sınıfına dahil edilmesi, 2009 yılında çıkarılan "iş Sağlığı ve Güvenliğine lilşkin Tehlike Sınıfları Listesi Tebliği” ile gerçekleşmiştir." Sağılık kuruluşları 30 Haziran 2012 tarih ve 6331 Sayılı iş Sağlığı ve Güvenliği isimli kanun ile kamu-özel ayıımı yapılmaksızın kapsama alınmış, işyeri hekimi ve iş güvenliği uzmanı çalıştırma zorunluluğu hastanelere de getirilmiştir. ${ }^{12}$

Yaşam kalitesi bireyin fiziksel işlevlerini, ruhsal durumunu, toplumsal ilişkilerini, çevreden etkilenilmişlik düzeyini kapsar. Ayrıca bireyin bu durumunun işlevselliğini ne derece etkilediğini gösterir. Günümüzde, sadece hastalıkların ortadan kaldıııması değil, kişilerin yaşam kalitelerinin arttııımaları da hedeflenmektedir. Bu nedenle iyilik hali ve yaşam kalitesinin ölçülebilmesi konusunda giderek artan bir çaba gösterilmektedir. Dünya Sağlık Örgütü (DSÖ) yaşam kalitesini ölçmek ve değerlendirmek amacıyla kişinin iyilik halini ölçen ve kültürler arası karşılaştırmalara olanak veren geniş kapsamlı 100 ve bunlardan seçilen 26 sorudan oluşan WHOQOL-BREF oluşturulmuştur. ${ }^{13,14}$ Bu çalışmanın amacı, bir üniversite hastanesinin yoğun bakım ünitelerinde vardiyalı sistemle çalışan hemşirelerin yaşam kalitesinin ve iş kazası geçirme oranlarının incelenmesidir.

\section{Gereç ve Yöntem}


hemşirelerin tamamı oluşturmuştur. Toplam 176 hemşirenin tamamına ulaşılması hedeflenmiştir. Ancak gebelik, doğum izni, hastalık, görevlendirme gibi nedenlerle izinli olma ve araştırmaya katılmayı kabul etmeme gibi nedenlerden dolayı çalışma 144 (evrenin \% 81’i) kişi ile Eylül-Ekim 2017 tarihleri arasında yapıldı.

Katılımcılara yaş, cinsiyet, medeni durum, çalışma şekli, çalıştığı bölüm, iş kazası geçirme durumundan oluşan sosyo-demografik ve mesleki özelliklerle ilgili toplam 15 soru içeren bir anket ve Türkiye'de geçerlilik ve güvenirlilik çalışmaları yapılmış Dünya Sağık Örgütü (DSÖ) Yaşam Kalitesi Ölçeği Kısa Formu Türkçe Versiyonu (WHOQOL-BREF-TR) uygulanmıştır. Anketler araştırmacı tarafından yüzyüze görüşme yöntemi ile doldurulmuştur.

Ölçeğin iç tutarlılığı için hesaplanan "cronbach alfa” değerleri bedensel alanda 0,83, ruhsal alanda 0,66 , sosyal alanda 0,53 , çevre alanında 0,73 ve ulusal çevre alanında 0,73 bulunmuştur. Testtekrar test güvenirliliğini hesaplamaya yönelik her soru için hesaplanan pearson katsayıları 0,57 ve 0,81 arasında değişmektedir. ${ }^{13}$

Türkçe geçerlilik çalışmaları sırasında bir ulusal soru eklenmesiyle oluşan WHOQOL-BREF-TR 27 sorudan oluşmaktadır. Soruların son 15 gün dikkate alınarak yanıtlanması istenmiştir. Illk iki genel soru dışındaki sorular kullanılarak bedensel, ruhsal, sosyal, çevre ve ulusal çevre alan puanları hesaplanmıştır. Türkçe Versiyonu (27. soru ulusal sorudur) kullanıldığında Çevre alan skoru çevreTR olarak adlandırılır. Bu durumda Çevre-TR alan skoru çevre skoru yerine kullanılır. Ölçek yaşlı olmayan yetişkinlere uygulanabilmektedir. ${ }^{13}$

Alanlara göre soruların içeriği şöyledir:

Bedensel alan: Gündelik işleri yürütebilme, ilaçlara ve tedaviye bağımlılık, canlılık ve bitkinlik, hareketlilik, ağrı ve rahatsızlık, uyku ve dinlenme ve çalışabilme gücü. $(3,4,10,15,16,17,18$. sorular olmak üzere yedi sorunun toplamı)

Ruhsal alan: Beden imgesi ve dış görünüş, olumsuz duygular, benlik saygısı, olumlu duygular, maneviyat, din, kişisel inançlar, düşünme, öğrenme, bellek ve dikkatini toplama. $(5,6,7,11,19$, 26. sorular olmak üzere altı sorunun toplamı)

Sosyal alan: Diğer kişilerle ilişkiler, sosyal destek, cinsel yaşam. (20, 21, 22. sorular olmak üzere üç sorunun toplamı)

Ulusal çevre alanı: Maddi kaynaklar, fiziksel güvenlik ve emniyet, sağlık hizmetleri ve sosyal yardım, ulaşılabilirlik ve nitelik, ev ortamı, yeni bilgi ve beceri edinme fırsatı, dinlenme ve boş zaman değerlendirme fırsatları ile bunlara katılabilme, fiziksel çevre (kirlilik, gürültü, trafik, iklim), ulaşım ve ulusal çevre alanı. $(8,9,12,13,14,23,24,25,27$. sorular olmak üzere dokuz sorunun toplamı) Ölçek sorularından en düşük beş puan alınmakta olup, her alanın toplam soru sayısı farklıdır. Dolayısıyla puan aralığı her alan için faklıdır. Alınan puan arttıkça yaşam kalitesi de artmaktadır. ${ }^{13}$

Bu araştırmanın bağımlı değişkenleri, yaşam kalitesi alan puanları ve geçirdikleri iş kazaları iken, bağımsız değişkenleri ise yaş, görev yaptığı yoğun bakım ünitesi, cinsiyet, meslekteki görev süresi, son bir yıl içinde izin kullanma durumu ve medeni durumdur.

Verilerin analizinde sosyo-demografik özellikler sayı ve yüzde dağılımı halinde verildi. Bağımlı-bağımsız değişkenler arasındaki ilişki için t testi ve ki-kare testi ile değerlendirildi. İstatistiksel analizler
Sakarya Tip Dergis 2018;8(1):99-107

YüzÜGüLLÜ

Bir Üniversite Hast. Yoğun Bakım Ünitesi Hemșirelerinde Yaşam Kalitesi, iş Kazaları ve Vardiyalı Çalışmanin Etkileri 
Araştırma için T.C. Çukurova Üniversitesi Tıp Fakültesi Girişimsel Olmayan Klinik Araştırmalar Etik Kurulundan 07.07.2017 tarihli ve 66 nolu toplantıda verilen karar ile izin alındı. Ayrıca Çukurova Üniversitesi Balcalı Hastanesi Başhekimliği'nden gerekli izin alındı.

\section{Bulgular}

Araştırma bir üniversite hastanesinin yoğun bakım ünitelerinde çalışan 144 hemşireye uygulanmıştır. Araştırmaya katılan yoğun bakım ünitesi hemşirelerinin yaş ortalaması 27,32 $\pm 5,72$ idi (min 19, max 50). Katılımcıların \% 80,6'sı kadın, \%52,8'i evli, \% 43,1'i çocuk sahibi idi. Araşıımaya katılan hemşirelerin \% 26,4'ü yenidoğan, \% 13,2'si dahiliye, \% 11,1'i çocuk, \% 10,4'ü genel cerrahi, \% 9,0'u beyin cerrahi, \% 7,6'sı reanimasyon, \% 7,6'sı kalp damar cerrahi, \% 7,6'sı koroner, \% 6,9'u nöroloji yoğun bakım ünitelerinde çalışmaktaydı. Katılımcıların \% 11,8'i alkol, \% 22,2'si sigara kullanmaktaydı ve \% 4,9'unun kronik hastalığı vardı (Tablo 1). Son bir yıl içinde \% 20,1'i izin kullanmamışıı ve \% 31,3'ü iş kazası geçirmiş̧i. Geçirilen iş kazalarının türüne baktığımızda ise, \% 83,4 'ü kesici-delici alet yaralanması, \% 4,9'u çarpma düşmeye bağlı yaralanmalar, \% 5,6'sı şiddete uğrama şeklinde idi (birden fazla seçenek işaretlenmiştir).

Tablo 1. Katılımcların Sosyodemografik Özelliklerinin Dağlımı

\begin{tabular}{|c|c|c|c|}
\hline \multicolumn{2}{|l|}{ Özellikler } & Sayı & $\%$ \\
\hline \multirow{3}{*}{ Yaş Grupları (yıl) } & $<30$ & 88 & 61,1 \\
\hline & $30-39$ & 51 & 35,4 \\
\hline & $\geq 40$ & 5 & 3,5 \\
\hline \multirow{2}{*}{ Cinsiyet } & Erkek & 28 & 19,4 \\
\hline & Kadın & 116 & 80,6 \\
\hline \multirow{3}{*}{ Meslekteki Yıl } & $\leq 5 \mathrm{yll}$ & 67 & 46,5 \\
\hline & 6-10 yıl & 48 & 33,3 \\
\hline & $\geq 11 \mathrm{yll}$ & 29 & 20,2 \\
\hline \multirow[b]{2}{*}{ Medeni Durum } & Evli & 76 & 52,8 \\
\hline & $\begin{array}{l}\text { Evli değil(bekar/ } \\
\text { boşanmış/dul) }\end{array}$ & 68 & 47,2 \\
\hline \multirow{2}{*}{ Çocuk Sahibi Olma } & Evet & 62 & 43,1 \\
\hline & Hayıг & 82 & 56,9 \\
\hline \multirow{2}{*}{ Sigara Kullanma } & Evet & 32 & 22,2 \\
\hline & Hayıг & 112 & 77,8 \\
\hline \multirow{2}{*}{ Alkol Kullanma } & Evet & 17 & 11,8 \\
\hline & Hayıг & 127 & 88,2 \\
\hline \multirow{2}{*}{ Kronik Hastalık } & Var & 7 & 4,9 \\
\hline & Yok & 137 & 95,1 \\
\hline Toplam & & 144 & 100,0 \\
\hline
\end{tabular}

Çalıştıkları bölümlere göre iş kazalarını incelediğimizde, son bir yılda en çok iş kazası geçirilen bölüm \% 60,0 ile Genel Cerrahi Yoğun Bakım Ünitesi iken, en az iş kazası geçirilen bölüm \% 18,2 ile Koroner Yoğun Bakım Ünitesi idi (Şekil 1).

Katılan hemşirelerin özelliklerine göre son bir yılda iş kazası geçirme dağılımlarına baktığımızda ise, meslekteki yıl arttıkça iş kazası geçirme oranı anlamlı olarak azalmakta $(p<0,001)$ idi. Erkek 
hemşireler anlamlı olarak daha fazla iş kazası geçirmişti $(p<0,001)$. Son bir yıl içinde izin kullanma durumunun iş kazası geçirme oranına anlamlı bir etkisi bulunamamışken, vardiyalı sistemle çalışan hemşireler son bir yıl içinde anlamlı olarak daha fazla iş kazası geçirmişti $(\rho=0,013)$ (Tablo 2).

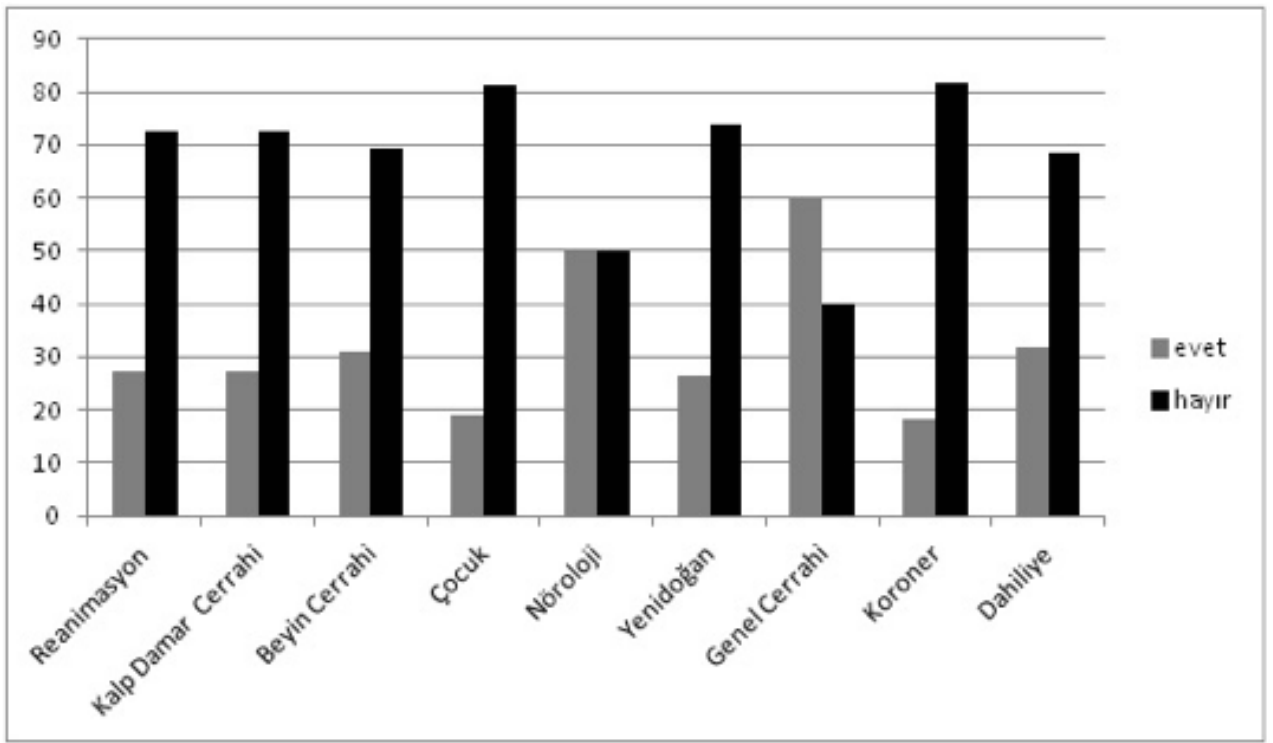

Şekil 1. Yoğun Bakım Ünitelerinde İş Kazası Geçirme Yüzdeleri

Tablo 2. Katılımcıların Özelliklerine Göre iş Kazası Geçirme Durumlarının Dağlımı

\begin{tabular}{|c|c|c|c|c|}
\hline & \multicolumn{2}{|c|}{ Son Bir Yıl İçinde iş Kazası Geçirme } & \multirow{2}{*}{ Toplam } & \multirow{2}{*}{$\mathrm{p}$} \\
\hline & Evet & Hayır & Sayı \%b \\
\hline
\end{tabular}

\begin{tabular}{|c|c|c|c|c|c|c|c|}
\hline \multicolumn{8}{|c|}{ Meslekteki Yıl } \\
\hline$\leq 5 \mathrm{yll}$ & 34 & 50,7 & 33 & 49,3 & 67 & 46,5 & \multirow{3}{*}{$<0,001$} \\
\hline 6-10 yll & 8 & 16,7 & 40 & 83,3 & 48 & 33,3 & \\
\hline$\geq 11 \mathrm{yll}$ & 3 & 10,3 & 26 & 89,7 & 29 & 20,2 & \\
\hline \multicolumn{8}{|l|}{ Cinsiyet } \\
\hline Erkek & 18 & 64,3 & 10 & 35,7 & 28 & 19,4 & \multirow{2}{*}{$<0,001$} \\
\hline Kadın & 27 & 23,3 & 89 & 76,7 & 116 & 80,6 & \\
\hline
\end{tabular}

Son Bir Yıl İçinde İzin Kullanma

\begin{tabular}{|l|l|l|l|l|l|l|l|}
\hline Evet & 32 & 27,8 & 83 & 72,2 & 115 & 79,9 & \multirow{2}{*}{0,078} \\
\cline { 1 - 6 } Hayıг & 13 & 44,8 & 16 & 55,2 & 29 & 20,1 & \\
\cline { 1 - 5 }
\end{tabular}

Vardiyalı Sistemle Çalışma

\begin{tabular}{|l|c|c|c|c|c|c|c|}
\hline Evet & 41 & 36,3 & 72 & 63,7 & 113 & 78,5 & \multirow{2}{*}{0,013} \\
\cline { 1 - 5 } Hayıг & 4 & 12,9 & 27 & 87,1 & 31 & 21,5 & \\
\hline $\begin{array}{l}\text { a= Satı yüzdesi } \\
\text { b= Kolon yüzdesi }\end{array}$ \\
\hline
\end{tabular}

Hemşirelerin WHOQOL-BREF-TR ölçeğinden aldıkları puan ortalamalarına baktığımızda, bedensel alan $24,64 \pm 4,22$, sosyal alan $9,62 \pm 2,73$, ruhsal alan $20,07 \pm 4,06$, çevre-TR alanı $26,93 \pm 4,61$ olduğunu görmekteyiz (Tablo 3 ).

Araştırmaya katılan hemşirelerin yaşam kalitesi puan dağıımlarını etkileyen faktörler incelenmiştir. Buna göre; erkek hemşirelerin sosyal alan, ruhsal alan ve çevre-TR alanı puanları anlamlı olarak
Sakarya Tip Dergis

2018;8(1):99-107

YüzÜGüLLÜ

Bir Üniversite Hast. Yoğun Bakım Ünitesi Hemşirelerinde Yaşam Kalitesi, iş Kazaları ve Vardiyalı Çalışmanin Etkileri 
daha düşüktü. Evli olmayanların evli olanlara göre sosyal, ruhsal ve çevre-TR alan puanları anlamlı olarak daha düşüktü. Son bir yıl içinde izin kullanmayanların sosyal alan puanı düşükken, vardiyalı sistemle çalışanların bedensel, sosyal, ruhsal ve çevre-TR alan puanları anlamlı olarak daha düşüktü (Tablo 4).

Tablo 3. Hemşirelerin WHOQOL-BREF-TR Ölçeğin Aldığı Puan Ortalamalarının Dağlımı

\begin{tabular}{|c|c|c|c|}
\hline WHOQOL-BREF-TR & Alınabilecek puan aralı̆̆ & Alınan puan aralığı & Ortalama değer \\
\hline Bedensel & $7-35$ & $11-35$ & $24,64 \pm 4,22$ \\
\hline Sosyal & $3-15$ & $3-15$ & $9,62 \pm 2,73$ \\
\hline Ruhsal & $6-30$ & $2-28$ & $20,07 \pm 4,06$ \\
\hline Çevre-TR & $9-45$ & $16-39$ & $26,93 \pm 4,61$ \\
\hline
\end{tabular}

Tablo 4. Katılımcıların Özelliklerine Göre Yaşam Kalitesi Ortalamalarının Dağlımı

\begin{tabular}{|c|c|c|c|c|c|c|c|c|}
\hline & \multicolumn{2}{|c|}{ Bedensel Alan } & \multicolumn{2}{|c|}{ Sosyal Alan } & \multicolumn{2}{|c|}{ Ruhsal Alan } & \multicolumn{2}{|c|}{ Çevre-TR Alan } \\
\hline & Mean-Sd & $\rho$ & Mean-Sd & $p$ & Mean-Sd & $p$ & Mean-Sd & $p$ \\
\hline \multicolumn{9}{|l|}{ Cinsiyet } \\
\hline Erkek & $24,39 \pm 3,37$ & \multirow{2}{*}{0,732} & $8,11 \pm 2,58$ & \multirow{2}{*}{0,001} & $17,86 \pm 3,69$ & \multirow{2}{*}{0,001} & $24,86 \pm 5,08$ & \multirow{2}{*}{0,008} \\
\hline Kadın & $24,70 \pm 4,41$ & & $9,98 \pm 2,64$ & & $20,60 \pm 3,98$ & & $27,43 \pm 4,36$ & \\
\hline \multicolumn{9}{|c|}{ Medeni Durum } \\
\hline Evli & $24,79 \pm 4,72$ & \multirow{2}{*}{0,648} & $10,46 \pm 2,71$ & \multirow{2}{*}{0,001} & $21,12 \pm 4,05$ & \multirow{2}{*}{$<0,001$} & $27,66 \pm 4,41$ & \multirow{2}{*}{0,045} \\
\hline Evli değil & $24,47 \pm 3,61$ & & $8,68 \pm 2,44$ & & $18,90 \pm 3,77$ & & $26,12 \pm 4,72$ & \\
\hline \multicolumn{9}{|c|}{ Son Bir Yılda İzin Kullanma } \\
\hline Evet & $24,80 \pm 4,37$ & \multirow{2}{*}{0,364} & $9,89 \pm 2,66$ & \multirow{2}{*}{0,018} & $20,33 \pm 4,02$ & \multirow{2}{*}{0,125} & $27,10 \pm 4,61$ & \multirow{2}{*}{0,394} \\
\hline Hayıг & $24,00 \pm 3,55$ & & $8,55 \pm 2,75$ & & $19,03 \pm 4,13$ & & $26,28 \pm 4,62$ & \\
\hline \multicolumn{9}{|c|}{ Vardiyalı Sistemle Çalışma } \\
\hline Evet & $24,00 \pm 3,92$ & \multirow{2}{*}{$<0,001$} & $9,05 \pm 2,53$ & \multirow{2}{*}{$<0,001$} & $19,35 \pm 4,11$ & \multirow{2}{*}{$<0,001$} & $26,49 \pm 4,57$ & \multirow{2}{*}{0,027} \\
\hline Hayıг & $26,97 \pm 4,50$ & & $11,68 \pm 2,42$ & & $22,71 \pm 2,54$ & & $28,55 \pm 4,44$ & \\
\hline
\end{tabular}

\section{Tartışma}

Yoğun bakım ünitelerinde görev yapan hemşireler ile yürütülen çalışmamızda, hemşirelerin sosyodemografik özellikleri, iş kazası geçirme durumları, vardiyalı çalışma sisteminin yaşam kalitesine etkileri incelenmiştir.

Araştırmamızda erkek olmanın, meslekteki tecrübenin az olmasının ve vardiyalı sistemle çalışmanın iş kazası geçirme oranını anlamlı olarak artırdığı sonucuna varılmıştır. Geçirilen iş kazasının türüne baktığımızda ise en sık kesici-delici alet yaralanmalarının olduğunu görmekteyiz. Bölümlere göre iş kazası geçirme oranlarını incelediğimizde ise en yüksek iş kazası geçirme yüzdesi \% 60,0 ile Genel Cerrahi Yoğun Bakım Ünitesindeyken, onu \% 50,0 ile Nöroloji Yoğun Bakım Ünitesi takip ediyordu (Şekil 1). 2005 ylında Hindistan'da sağlık çalışanlarında yapılan bir çalışmada da, çalışmaya katılanların dörtte üçü iş yaşamları boyunca en az bir kez delici-kesici alet yaralanması geçirdiklerini bildirmişlerdir. ${ }^{15} 2006$ yılında Ege Üniversitesinde yapılan çalışmada da bizim çalışmamıza benzer şekilde iş kazası geçiren personelde en fazla iğne batması meydana geldiği belirtilmiştir. ${ }^{16}$ Sonuçlar çalışmamızla benzerlik göstermektedir.

Hastanelerde risk oluşmadan önlem alınması hasta ve sağılık personeli güvenliği açısından büyük 
öneme sahiptir. Hastanelerde öncelikle yüksek risk içeren her türlü faaliyetin belirlenmesi, tıbbi hataların ceza alma korkusu olmadan bildirilebildiği bir işyeri ortamı yaratılması ve çalışanlar ile hastalar için daha güvenli bir ortam yaratabilmek için nitelikli sağlık personeli, nitelikli sağlık kuruluşları gibi gerekli kaynaklar sağlanması gerekmektedir. ${ }^{17}$

Vardiyalı çalışma sistemi hemşirelerin iş kazalarında artış ve yaşam kalitesinde bozulma gibi problemleri de beraberinde getirmiştir. Vardiyalı sistemle çalışan yoğun bakım hemşirelerinin \% 36,3'ü son bir yıl içinde iş kazası geçirmişken bu oran vardiyalı sistemle çalışmayanlarda $\% 12,9^{\prime} \mathrm{du}$. Aradaki fark istatistiksel olarak anlamlıydı. 2009 ylında Ankara'da yapılan Hemşirelerde iş Kazası Sıklığı çalışmasına göre gündüz-gece şeklinde çalışanlarda kesici-delici-batıcı cisim yaralanması $\%$ 73,5 olarak tespit edilmiştir. Ayrıca hemşirelerin aylık toplam fazla mesai durumlarına göre, iş kazası geçirme durumları karşılaştıııldığında; aylık toplam fazla mesai saati arttıkça iş kazası geçirme riskinin arttı̆̆ı görülmüştür. ${ }^{18}$

Ankara'da bir üniversite hastanesindeki sağlık personelinde yapılan bir çalışmada günde 8 saat sistemiyle çalışan grupta kesici-delici-batıcı cisim yaralanması $\% 56,6$ iken, günde 8 saat + nöbet ve vardiya sistemiyle çalışan grupta yaralanma sıklığı daha yüksek bulunmuştur. ${ }^{19}$ Benzer şekilde bizim çalışmamızda da, vardiyalı sistemle çalışan hemşireler, gündüz mesaisine gelen hemşirelere göre daha fazla iş kazası geçirmiştir. Bu konuda daha önce yapılan çalışmaların ve bizim çalışmamızın sonuçlarına baktığımızda, vardiyalı sistemle çalışmanın uyku bozuklukluklarına yol açarak yaşam kalitesini düşürdüğü, bunun sonucunda da hemşirelerde dikkat dağınıklığı, yorgunluk gibi sebeplerle iş kazalarının arttı̆̆ yorumunu yapabiliriz.

Çalışmamızda WHOQOL-BREF-TR Yaşam Kalitesi Ölçeğinden aldıkları puanlara baktığımızda, vardiyalı sistemle çalışan hemşirelerin bedensel, sosyal, ruhsal ve çevre-TR alan puanları anlamlı olarak daha düşüktü.

Kavlu ve arkadaşlarının acil servislerde çalışan 322 hemşire ile yapılan bir çalışmasında ise, hemşirelerin yaklaşık yarısının tükenmişlik yaşadığı ve tükenmişlik arttıkça iş doyumu ve yaşam kalitesinin azaldığı belirlenmiştir. ${ }^{20}$ Bu sonuç, hemşirelerin yaşadığı psikiyatrik problemlerin yaşam kalitesiyle bağlantılı olduğunu aklımıza getirmektedir. İş yerinde karşılaştıkları olumsuzluklar, düzensiz uyku, yoğun çalışma temposu gibi nedenlerin hemşirelerdeki tükenmişliği, dolayısıyla yaşam kalitesindeki bozulmayı artırdığını düşünebiliriz.

Çalışmamızda cinsiyete göre yaşam kalitesini incelediğimizde, erkek hemşirelerin sosyal alan, ruhsal alan ve çevre-TR alan puanları kadın hemşirelere göre daha düşüktü. Yıldııım ve arkadaşlarının sağık çalışanlarında yaşam kalitesini inceledikleri çalışmalarında yapılan çoklu analiz sonucunda erkeklerin yaşam kalitesi çevre alt boyutu puan ortalamalarının kadınlara göre daha fazla olduğu görülmüştür. ${ }^{21}$ Yapılan bazı çalışmalarda erkeklerin yaşam kalitesi düzeyinin kadınlardan daha fazla olduğu belirlenirken, ${ }^{22,23}$ bazılarında cinsiyetin yaşam kalitesinde etkili olmadığı belirlenmiştir. ${ }^{24,25}$ Bu konuda çalışmamızda literatürle farklı sonuçlar elde edilmiştir. Fakat çalışmamıza katılan erkek hemşirelerin \% 96,4'ü evli değilken, kadın hemşirelerin ise \% 35,3'ü evli değildi. Yani erkek hemşirelerin çoğunluğunun evli olmaması yaşam kalitelerini olumsuz yönde etkilemiş olabilir.

Bizim çalışmamızda evli olanların sosyal, ruhsal ve çevre-TR alan puanları, evli olmayanlara göre
Sakarya Tip Dergis 2018;8(1):99-107

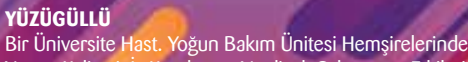
Yaşam Kalitesi, iş Kazaları ve Vardiyalı Çalışmanın Etkileri 
1. Kaçmaz N. Tükenmişlik sendromu. İst Tip Fak Derg 2005; 68:29-32.

2. Yıldııım A, Hacıhasanoğlu R. Sağlık çalıșanlarında yaşam kalitesi ve etkileyen değişkenler. Journal of Psychiatric nursing 2011; 2(2), 61-8.

3. Yıldırım A, Hacıhasanoğlu R. Sağlık çalıșanlarında yașam kalitesi ve etkileyen değişkenler. Journal of Psychiatric nursing 2011; 2(2), 61-8.

4. Huth JJ, Eliades A, Handwork C, Englehart JL, Messenger J. Shift worked, quality of sleep, and elevated body mass index in pediatric nurses. Journal of pediatric nursing 2013; 28(6), e64-e73.

5. Karhula K, HÄRMÄ M, Sallinen M, Hublin C, Virkkala J, KIVIMÄKI M., et al. Job strain, sleep and alertness in shift working health care professionals-a field study. Industrial health 2013; 51(4), 406-416.

6. Lin SH, Liao WC, Chen MY, Fan JY. The impact of shift work on nurses' job stress, sleep quality and self perceived health status. Journal of nursing management 2014; 22(5), 604-612.

7. Chin W, Guo YL, Hung YJ, Yang CY, Shiao JSC. Short sleep duration is dose-dependently related to job strain and burnout in nurses: a cross sectional survey. International journal of nursing studies, 2015; 52(1), 297-306.

8. Wisetborisut A, Angkurawaranon C, Jiraporncharoen W, Uaphanthasath R, Wiwatanadate P. Shift work and burnout among health care workers. Occupational Medicine 2014; 64(4), 279-286.

9. Zencirci $A D$, Arslan S. Morning-evening type and burnout level as factors influencing sleep quality of shift nurses: a questionnaire study. Croatian medical journal 2011; 52(4), 527-537.

10.ILO. Occupational Injuries Statistics From Household Surveys and Establishment Surveys; 2008. Erişim: http://www.ilo.org/wcmsp5/ groups/public/---dgreports/-.-stat/documents/publication/ wcms_173153.pdf (Erişim tarihi: 09/01/2018)

11. İșyeri Tehlike Sınıfları Listesi, İş Sağlığı ve Güvenliğine Ilişkin İşyeri Tehlike Sınıfları Tebliği, 2012

12.6331 Sayılı İs Sağı̆ğı ve Güvenliği Kanunu. Resmi Gazete Sayı: 28339, 2012.

13. Eser E, Fidaner H, Fidaner C, Eser SY, Elbi H, Göker E. Psychometric properties of WHOQOL-100 and WHOQOL-BREF. 3P Dergisi 1999; 7 (2 Suppl.):23-40.

14. Eser SY, Fidaner H, Fidaner C, Elbi H, Eser E, Göker E. Measure of quality of life WHOQOL- 100 and WHOQOL-Bref. 3P Dergisi 1999 , 7(2 Suppl.):5-13.

15. Kermode M, Jolley D. Occupational Exposure to Blood and Risk of Bloodborne Virus İnfection Among Health Care Workers in Rural North Indian Health Care Settings. American Journal of Infection Control; 2005: 37 .

16. Çopur Z, Varlı B. Ege Üniversitesi Hastanesinde Çalışan Ev İdaresi Personelinin İs Kazası Geçirme Durumlarının İncelenmesi. Hacettepe Sağlık İdaresi Dergisi; 2006: 162-168.

17. Çırpı F, Merih YD, Kocabey MY. Hasta Güvenliğine Yönelik Hemşirelik Uygulamalarının ve Hemşirelerin Bu Konudaki Görüşlerinin Belirlenmesi. Maltepe Üniversitesi Hemşirelik Bilim ve Sanatı Dergisi, 2009, 2(3),26-34.

18. Özarslan A. Ankara'da Bir Eğitim Hastanesinde Çalışan Hemşirelerde iş Kazası Sıklı̆ı. Yüksek Lisans Tezi, Gazi Üniversitesi Halk Sağlığı Anabilim Dali, Ankara; 2009.

19.Dikmen AU, Medeni V, Uslu I, Altun B, Aycan S. Ankara'da Bir Üniversite Hastanesinde Çalışan Sağlık Personelinin Geçirdiğini ifade Ettiğ İş Kazalarının Değerlendirilmesi. Mesleki Sağlık ve Güvenlik Dergisi (MSG) 2015; 14(53).

20.Kavlu I, Pınar R. Acil servislerde çalışan hemşirelerin tükenmişlik ve iş doyumlarının yaşam kalitesine etkisi. Türkiye Klinikleri J Med Sci 2009; 29:1543-55.

21.Yıldııım A, Hacıhasanoğlu R. Sağlık çalışanlarında yașam kalitesi ve et kileyen değişkenler. Journal of Psychiatric nursing 2011; 2(2), 61-8.

22. Yeşil A, Ergün Ü, Amasyalı C, Er F Olgun NN, Aker AT. Çalışanlar için yaşam kalitesi ölçeği Türkçe uyarlaması geçerlik ve güvenilirlik çalışması. Nöropsikiyatri Arșivi 2010; 47:111-7.

23. Musaoğlu Z. Trakya Üniversitesi öğretim elemanlarının sağıkla ilintili yaşam kalitesi. Uzmanlık Tezi, Trakya Üniversitesi Tıp Fakültesi Aile Hekimliği ABD, Edirne, 2008.

24.Avcı K, Pala K. Uludağ Üniversitesi Tip Fakültesi'nde çalışan araştırma görevlisi ve uzman doktorların yaşam kalitesinin değerlendirilmesi. Uludağ Üniversitesi Tıp Fakültesi Dergisi 2004; 30:81-5.

25. Chien LY, Lo LH, Chen CJ, Chen YC, Chiang CC, Yu Chao YM. Quality of life among primary caregivers of Taiwanese children with brain tumor. Cancer Nurs 2003; 26:305- 11.

26. Ergün FS, Oran NT, Bender CM. Quality of life of oncology nurses. Cancer Nurs 2005; 28:193-9.
27. Cimete G, Gencalp NS, Keskin G. Quality of life and job satisfaction of nurses. J Nurs Care Qual 2003; 18:151-8.

28. Kaya M, Piyal B. Ankara'da 112 acil yardım hizmetlerinde çalışan personelin öznel yașam kalitelerinin sosyo-demografik özellikler yönünden yaşam kalitesi ait alanlarına göre değerlendirilmesi. 1. Sağılıta Yaşam Kalitesi Sempozyumu, Özet Kitabı. İzmir: 2004; s.61.

29. Bilazer FN, Konca GE, Uğur S, Uçak H, Erdemir F, Çıtak E. Türkiye'de Hemşirelerin Çalışma Koşulları. Türk Hemşireler Derneği Yayınları 2008. Erișim: http://turkhemsirelerdernegi.org.tr/tr/yayinlar/thdyayinlari/brosurler-ve-raporlar/turkiyede-hemsirelerin-calisma-kosullari.aspx (Erişim Tarihi: 15.01.2018)

30.Perhats C, Keough V, Fogarty J, Hughes NL, Kappelman CJ, Scott M, Moretz J. Non-Violence-Related Work Place İnjuries Among Emergency Nurses in The United States: İmplications Form Proving Safe Practice, Safe Care, Journal Of Emergency Nursing 2012; 38(6), 541 548.

31. Özkan Ö, Emiroğlu ON. Hastane Sağlık Çalışanlarına Yönelik Iş̧̧̧i Sağlığı ve İs Güvenliği Hizmetleri. C.Ü.Hemșirelik Yüksekokulu Dergisi, 2006; 10 (3), 43-51.

32. Tanrıverdi H, Akova O, Latifoğlu NT. Yenidoğan yoğun bakım ünitelerinde iş kazaları riskleri ve nedenlerine yönelik bir araştırma. Business And Management Studies: An International Journal 2015; 3(2).

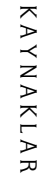

Sakarya Tıp Dergis 2018;8(1):99-107

YüzÜGÜLLÜ

Bir Üniversite Hast. Yoğun Bakım Ünitesi Hemşirelerinde

Yaşam Kalitesi, iş Kazaları ve Vardiyalı Çalışmanın Etkileri 